\title{
Bactrospora totonacae (Arthoniales, Ascomycota), a new species from Veracruz, Mexico
}

\section{Bactrospora totonacae (Arthoniales, Ascomycota), una nueva especie de Veracruz, México}

\section{Acta Botanica Mexicana}

\author{
Jorge Guzmán-Guillermo1,4 (iD, Paola L. Sorcia-Navarrete² (iD, Régulo C. Llarena-Hernández' \\ Kevin Dorian R. Cárdenas-Mendoza ${ }^{3}$
}

\begin{abstract}
:
Background and Aims: Bactrospora is a genus of crustose lichens characterized by its black, verrucose to denticulate and little apothecia, and mostly acicular, or sometimes muriform spores, longer than wide. The genus is represented by 38 accepted species. The aim of this work is to describe Bactrospora totonacae, a new species from the tropical dry forest of Veracruz, Mexico.

Methods: The specimens were collected on the "Cerro de los Metates" in the municipality of Actopan, Veracruz, Mexico. Macrochemical tests, UV reaction, and a thin layer chromatography were performed; likewise, the presence of amyloid substances distributed in the thallus and ascomata was verified with Lugol's solution. The voucher is deposited in the herbarium XALU of the Facultad de Biología of the Universidad Veracruzana.

Key results: The new species Bactrospora totonacae is characterized by the pruine $\mathrm{K}+$ reddish magenta in its disc.

Conclusions: The described species is unique in Bactrospora because the combination of pruine K+ reddish magenta and a thick carbonized exciple has never been reported in this genus.
\end{abstract}

Key words: Opegraphaceae, Roccellaceae, tropical dry forest.

\section{Resumen:}

Antecedentes y Objetivos: Bactrospora es un género de líquenes costrosos que se caracteriza por el color negro, aspecto verrucoso a denticulado y pequeño de sus apotecios, posee esporas mayoritariamente aciculares y en ocasiones muriformes, pero siempre más largas que anchas. El género está representado por 38 especies aceptadas. El objetivo de este trabajo es describir Bactrospora totonacae, una especie nueva del bosque tropical seco de Veracruz, México.

Métodos: Los especímenes fueron recolectados en el "Cerro de los Metates", municipio Actopan, Veracruz, México. Se realizaron pruebas macroquímicas, reacción UV y cromatografía en capa fina; asimismo, con la solución de Lugol se verificó la presencia de sustancias amiloides distribuidas en el talo y el ascoma. Las muestras estudiadas se depositaron en el herbario XALU de la Facultad de Biología de la Universidad Veracruzana.

Resultados clave: La nueva especie Bactrospora totonacae se caracteriza por presentar pruina K + magenta rojizo en el disco.

Conclusiones: La especie que se describe en Bactrospora es única porque la combinación de pruina $\mathrm{K}+$ magenta rojizo y un excípulo carbonizado y grueso no había sido reportada en alguna otra especie de este género.

Palabras clave: bosque tropical seco, Opegraphaceae, Roccellaceae.

\author{
${ }^{1}$ Universidad Veracruzana, Facultad de Ciencias Bioló- \\ gicas y Agropecuarias, Peñuela, 94945 Amatlán de los \\ Reyes, Veracruz, Mexico. \\ ${ }^{2}$ Universidad Veracruzana, Centro de Investigaciones \\ Tropicales, 91000 Xalapa, Veracruz, Mexico. \\ ${ }^{3}$ Universidad Veracruzana, Facultad de Biología, 91000 \\ Xalapa, Veracruz, Mexico. \\ ${ }^{4}$ Author for correspondence: qwerty.guzmi@gmail. \\ com
}

Received: May 18, 2021.

Reviewed: June 1, 2021.

Accepted by Marie-Stéphanie Samain: September 8, 2021.

Published Online first: September 17, 2021.

Published: Acta Botanica Mexicana 128 (2021).
To cite as: Guzmán-Guillermos, J., P. L. Sorcia-Navarrete, R. C. Llanera-Hernández and K. D. R. Cárdenas-Mendoza. 2021. Bactrospora totonacae (Arthoniales, Ascomycota), a new species from Veracruz, Mexico. Acta Botanica Mexicana 128: e1900. DOI: https://doi. org/10.21829/abm128.2021.1900

e-ISSN: $2448-7589$ 


\section{Introduction}

The order Arthoniales is the third-largest order of lichenized fungi, with more than 1900 species, distributed in seven families and 105 genera (Lücking et al., 2017). The lichenized taxa generally have crustose growth, colonizing a wide variety of substrates, from saxicolous, corticolous, lignicolous to foliicolous, and are especially abundant and diverse towards the coasts (Ertz and Tehler, 2011), where fruticose species such as those belonging to Roccella Bory are also frequent (Tehler, 2011; Guzmán-Guillermo, et al., 2020).

Bactrospora A. Massal is a crustose genus characterized by its black, verrucose to denticulate and little apothecia, mostly acicular and sometimes muriform spores, usually longer than wide, and its particular Bactrospora-type asci (Egea and Torrente, 1993). The genus is represented by approximately 38 species, considering the 34 accepted species (Lücking et al., 2017; Wijayawardene et al., 2018) and some of them recently described (van den Boom et al., 2018; Herrera-Campos et al., 2019). Bactrospora has a cosmopolitan distribution, both in tropical and temperate ecosystems (Egea and Torrente, 1993; Sobreira et al., 2015), with several species that are only known from the type locality (Egea and Torrente, 1993; Sobreira et al., 2015). This can be explained since Bactrospora specimens can be confused with non-lichenized fungi, being discarded by lichenologists (Sobreira et al., 2015). According to Grube (1998) and Sobreira et al. (2015), this genus belongs to the family Roccellaceae. However, recent studies failed to confirm its relation to this family, since there are still no available sequences of the genus that allow to clarify its phylogenetic relationships (Lücking et al., 2017). Therefore, the position of the genus Bactrospora within the order Arthoniales must be treated as incertae sedis at the family level (Siljo et al., 2021).

In Mexico, three species of Bactrospora are known. Guzmán-Guillermo et al. (2019) and García-Martinez et al. (2021) reported Bactrospora jenikii (Vězda) Egea \& Torrente and Bactrospora denticulata (Vain.) Egea \& Torrente, respectively from coastal ecosystems in Quintana Roo (southeastern Mexico) and Herrera-Campos et al. (2019) described Bactrospora lecanorina Herrera-Camp., Altamirano \& Lücking from Jalisco. The current systematics of this genus follows the combination of characters like shape, measures, and amiloidity of its apothecia and the type of its spores, since the morphology is somewhat simple. According to Egea and Torrente (1993), the genus has four types of spores: Dryina-type, Homolotropa-type, Jenikii-type and Patellarioides-type. Furthermore, recent studies have recognized the presence and chemistry of pruina as an important character for the delimitation of species concept within Bactrospora (Berger and Aptroot, 2008; van den Boom et al., 2018).

In the present contribution, we describe Bactrospora totonacae Guzmán-Guillermo, Sorcia-Navarrete \& Cárdenas-Mendoza as new to science, as part of the ongoing project of the microlichen funga of Veracruz, mainly focused on the tropical dry forest in coastal ecosystems.

\section{Materials and Methods}

The material here studied was collected in vegetation related to tropical dry forest near the "Cerro de los Metates" (1940'07.7"N, 96²4'51.7'W, 175 m a.s.I.) in Actopan, Veracruz, Mexico, in 2019 and 2020 (Fig. 1). Specimens were placed in paper bags and transported to the herbarium XALU of the Facultad de Biología of the Universidad Veracruzana, where they were sterilized by freezing. The specimens were analyzed by a stereomicroscope model Stemi Dv4 (Carl Zeiss, Jena, Germany) and microscopic structures were measured with a model Primo Star microscope (Carl Zeiss, Jena, Germany), in the Laboratory of Environmental Quality of the Facultad de Biología of the Universidad Veracruzana. The terminology and characteristics considered in this work follow the concepts of Egea and Torrente (1993). In addition to the macrochemical tests $\mathrm{KOH} 10 \%(\mathrm{~K}), \mathrm{NaClO}(\mathrm{C})$, and $\mathrm{KC}$ (modification of $\mathrm{K}$ and $\mathrm{C}$ ), and $\mathrm{UV}$ reaction, lichen substances were searched employing thin layer chromatography (TLC) in solvent C (Elix, 2014). Likewise, the presence of amyloid substances distributed in the thallus and ascoma was verified with Lugol's solution (I), performing a pretreatment (IKI) of sections of the thallus and ascomas with potassium hydroxide ( $\mathrm{KOH} 10 \%)$.

\section{Results}

\section{Taxonomy}

Bactrospora totonacae Guzmán-Guillermo, Sorcia-Navarrete \& Cárdenas-Mendoza, sp. nov. Fig. 2. 




Figure 1: Type locality of Bactrospora totonacae Guzmán-Guillermo, Sorcia-Navarrete \& Cárdenas-Mendoza, Veracruz, Mexico.

MycoBank No.: MB 841138

TYPE: MEXICO. Veracruz, municipality of Actopan, Cerro de los Metates, 07.XII.2019, J. Guzmán-Guillermo 1181$A$ (holotype: XALU!).

Bactrospora totonacae differs from all Bactrospora species with thick carbonized excipulum and Patellaroides-type spores by its yellow crystals K+ magenta red. Only B. ochracea is similar in its chemistry, but differs from the new species by the carbonized excipulum.

Thallus crustose, whitish, and very thin; apothecia black, sessile, $0.5-1 \mathrm{~mm}$, with a thick carbonized exciple of
40-150 $\mu \mathrm{m}$ and $\mathrm{KI}-$, verrucose at the margin and open below the subhymenium; disc covered with conspicuous yellow crystals; paraphysoids with branched tips, not anastomosed, forming a yellow pseudoepithecium that changes to reddish magenta in $\mathrm{K}$; hymenium not inspersed, hyaline 110 $\mu \mathrm{m}$ tall, I+ red, $\mathrm{KI}-$; subhymenium $50 \mu \mathrm{m}$ tall, $\mathrm{KI}+$ blue; asci 8-spored, Bactrospora-type, 110-124 × 10-11 $\mu \mathrm{m}$, tholus $\mathrm{KI}+$ blue; spores Patellaroides-type, non-spiraled, without constrictions nor breaking into smaller fragments, 70-85 $\times$ (1.5)2-2.5 $\mu \mathrm{m}$ with (13)14-16 septa, I-; pycnidia not seen.

Etymology: the epithet refers to the culture "Totonaca" because the type locality was a prehispanic cemetery of this indigenous group. The Totonac played an essential role 




Figure 2: Holotype of Bactrospora totonacae Guzmán-Guillermo, Sorcia-Navarrete \& Cárdenas-Mendoza. A-B. apothecia with yellow crystals (scale: $\mathrm{A}=0.5 \mathrm{~mm} ; \mathrm{B}=1 \mathrm{~mm}$ ); C. subhymenium after KI (scale: $10 \mu \mathrm{m}) ; \mathrm{D}$. asci and paraphysoids after KI (scale: $30 \mu \mathrm{m}) ; \mathrm{E}$. ascospores (scale: $7.5 \mu \mathrm{m}) ; \mathrm{F}$. yellow pseudoepithecium in water (scale: $20 \mu \mathrm{m}$ ); G. pseudoepithecium in K, the color change is visible (scale: $20 \mu \mathrm{m}$ ); $\mathrm{H}$. yellow crystals found on the disc in water (arrows) (scale: $10 \mu \mathrm{m}$ ). 
in the history of Mexico since they allied with the Spanish army during the conquest of the Aztec empire.

Chemistry: thallus C-, K-, UV-; crystals on the disk C-, $\mathrm{K}+$ reddish magenta; excipulum $\mathrm{K}+$ greenish-brown. TLC: no lichen substances were detected. A TLC for the yellow pigment was not performed, but due to the coloration in $\mathrm{KOH}(10 \%)$, it is considered a compound related to an anthraquinone, possibly the same as Bactrospora ochracea Ertz \& van den Boom (van den Boom et al., 2018).

Macroecology: corticolous on Manilkara sp., growing with Bactrospora myriadea (Fée) Egea \& Torrente, Cresponea sp. and Trypethelium eluteriae Spreng. in the tropical dry forest of the "Cerro de los Metates" in the municipality of Actopan, very close to the coast of the Gulf of Mexico. This locality is very promising for the study of Arthoniales, where we reported Rocccella gracilis Bory for the first time on the Mexican side of the Gulf of Mexico (Guzmán-Guillermo et al., 2020).

Distribution: only known from its type locality.

Additional specimens studied: MEXICO. Veracruz, municipality of Actopan, Cerro de los Metates, 07.XII.2019, J. Guzmán-Guillermo 1168 (XALU); loc. cit., 21.XII.2020. J. Guzmán-Guillermo 2853 (XALU), 2854 (XALU).

Notes: Bactrospora totonacae is characterized by the pruine $\mathrm{K}+$ reddish magenta in its disc. It is unique within the genus due to the combination of pruine $\mathrm{K}+$ reddish magenta and a thick carbonized exciple, that has never been reported in Bactrospora.

\section{Discussion}

According to the shape and measurements of the Bactrospora totonacae spores, it is similar to widely distributed species such as $B$. denticulata, B. myriadea, and B. acicularis (C. W. Dodge) Egea \& Torrente, and other similar species with Patellaroides-type spores. It differs from the latter species because none of them have yellow $\mathrm{K}+$ magenta-reddish pruine on any part of the apothecia. The literature mentions that $B$. myriadea has yellow pruine granules that can occasionally be seen without the need of sections (Egea and Torrente 1993; Sobreira et al., 2015), but these granules do not react to K. Two other species of Bactrospora are known to possess conspicuous yellow pruine on the disc or spread over the margin: Bactrospora flavopruinosa F. Berger \& Aptroot and B. ochracea. Bactrospora totonacae differs from $B$. flavopruinosa because the latter has considerably smaller spores (45-55 × 1.5-2.5 $\mu \mathrm{m}$, 9-15-septate) and the yellow pruine does not generate a reddish-magenta $\mathrm{K}+$ coloration (Berger and Aptroot, 2008). On the other hand, B. ochracea, a recently described species from Suriname, has an ascocarp covered by a yellow bloom that reacts $\mathrm{K}+$ reddish magenta, it differs in the size and number of septa of its spores, $(40.0-50.0 \times(3-) 4-5(-6)$ $\mu \mathrm{m}, 7-13$-septate (van den Boom et al., 2018). In addition, B. ochracea has an unusual ascocarp in the genus Bactrospora, since it does not have a carbonized exciple (van den Boom et al., 2018), which is evident in B. totonacae.

\section{Author contributions}

JGG designed and directed the research. JGG, PSN and KCM collected the specimens here studied, JGG and RLH wrote the document and JGG and PSN illustrated the manuscript.

\section{Funding}

This study was supported by private funding of the authors.

\section{Acknowledgements}

We would like to thank Clementina Barrera Bernal from the Laboratory of Environmental Quality of the Facultad de Biología of the Universidad Veracruzana and Facundo Ortega, curator of Herbarium XALU, who made the realization this work possible. We are grateful to the reviewers for their useful comments.

\section{Literature cited}

Berger, F. and A. Aptroot. 2008. Bactrospora flavopruinosa, a new lichen species from Bermuda. Lichenologist 40(6): 543-547. DOI: https://doi.org/10.1017/s0024282908008104

Egea, J. M. and P. Torrente. 1993. The lichen genus Bactrospora. Lichenologist 25: 211-255. 
Elix, J. A. 2014. A catalogue of standardized chromatographic data and biosynthetic relationships for lichen substances. Third Edition. Canberra, Australia. 323 pp.

Ertz, D. and A. Tehler. 2011. The phylogeny of Arthoniales (Pezizomycotina) inferred from nucLSU and RPB2 sequences. Fungal Diversity 49: 47-71. DOI: https://doi.org/10.1007/ s13225-010-0080-y

García-Martínez, Y. A., A. G. Heredia, J. Guzmán-Guillermo, R. Valenzuela and T. Raymundo. 2021. Hongos asociados al mangle rojo Rhizophora mangle (Rhizophoraceae) en la Reserva de la Biosfera Isla Cozumel, Quintana Roo, México. Acta Botanica Mexicana 128: e1792. DOI: https://doi. org/10.21829/abm128.2021.1792

Grube, M. 1998. Classification and phylogeny in the Arthoniales (Lichenized Ascomycetes). Bryologist 101(3): 377-391. DOI: https://doi.org/10.2307/3244176

Guzmán-Guillermo, J., C. B. Bernal and G. T. Cantú. 2020. Primer registro del género Roccella (Ascomycota: Roccellaceae) para las costas mexicanas del Golfo de México. UVserva 9: 96-104. DOI: https://doi.org/10.25009/uvserva.v0i9.2633

Guzmán-Guillermo, J., A. Huereca and K. D. Cárdenas-Mendoza. 2019. Nuevos registros de líquenes de Quintana Roo, México. Boletín Micológico 34: 25-32. DOI:

Herrera-Campos, M. A., A. Barcenas-Peña, R. Miranda-González, M. Altamirano-Mejía, J. A. Bautista-González, P. MartínezColín, N. Sánchez-Téllez and R. Lücking. 2019. New lichenized Arthoniales and Ostropales from Mexican season- ally dry tropical forest. The Bryologist 122(1): 62-83. DOI: https://doi.org/10.1639/0007-2745-122.1.062

Lücking, R., B. P. Hodkinson and S. D. Leavitt. 2017. The 2016 classification of lichenized fungi in the Ascomycota and Basidiomycota-approaching one thousand genera. Bryologist 119(4): 361-416. DOI: https://doi.org/10.1639/0007-2745119.4.361

Siljo, J., S. Nayaka and G. Prasad. 2021. On the taxonomic identity of Bactrospora lamprospora (lichenized Ascomycota: Arthoniales). Archive for Lichenology 25: 1-5.

Sobreira, P. N., A. Aptroot and M. E. da Silva Cáceres. 2015. A world key to species of the genus Bactrospora (Roccellaceae) with a new species from Brazil. Lichenologist 47(2): 131136. DOI: https://doi.org/10.1017/S0024282914000607

Tehler, A. 2011. Roccella, the Sonoran species reviewed. Bibliotheca Lichenologica 106: 309-318.

van den Boom, P. P., H. J. Sipman, P. K. Divakar and D. Ertz. 2018. New or interesting records of lichens and lichenicolous fungi from Suriname, with descriptions of eight new species. Ascomycete.org 10(6): 244-258. DOI: https://doi org/10.25664/ART-0248

Wijayawardene, N. N., K. D. Hyde, H. T. Lumbsch, J. K. Liu, S. S. Maharachchikumbura, A. H. Ekanayaka, Q. Tian and R. Phookamsak. 2018. Outline of Ascomycota: 2017. Fungal Diversity 88: 167-263. DOI: https://doi.org/10.1007/ s13225-018-0394-8 